\title{
NASTROJE SPOŁECZNE W RUMUNII \\ U PROGU REWOLUCJI 1989 ROKU W ŚWIETLE RELACJI POLSKIEJ AMBASADY W BUKARESZCIE
}

\author{
AGNIESZKA KASTORY
}

\begin{abstract}
Social moods in Romania at the brink of the revolution of 1989 in the light of the reports from the Polish embassy in Bucharest.

The aim of the article is to show the perception of the situation in Romania before the so-called Romanian revolution of 1989 on the basis of the notes and reports from the Polish embassy in Bucharest. Different texts of Romanian dissidents, critical towards the communist regime of Nicolae Ceauşescu, were included in these sources. The Polish officials noticed each manifestation of resistance against the regime and followed the process of concretization of an organized opposition. From their point of view, isolated protests, expressed in the form of open letters to President Ceauşescu or the chairman of the Writers' Union, did not foreshadow any imminent fall of the Romanian dictator. However, they became the evidence of the Romanians' complete rejection of the existing political system. The content and form of all interpreted protests show understanding and correct recognition of the sources of the catastrophic situation of Romania. The events of December 1989 confirmed that Romanians were ready to completely reject the existing social, economic and political system.
\end{abstract}

STRESZCZEnIE. Tekst powstał w oparciu o notatki opracowywane w 1989 roku przez polską ambasadę w Bukareszcie i dołączane do nich rożne teksy rumuńskich dysydentów, krytyczne wobec reżimu Nicoale Ceauşescu. Urzędnicy ambasady odnotowywali każdy przejaw sprzeciwu i oczekiwali pojawienia się zorganizowanej opozycji politycznej. Z ich punktu widzenia odosobnione akty protestu, kierowane w postaci listów otwartych do Prezydenta N. Ceauşescu czy przewodniczącego Związku Pisarzy, nie zwiastowały szybkiego upadku dyktatora. W kontekście wydarzeń z grudnia 1989 roku należy jednak uznać te protesty za świadectwo odrzucenia istniejącego systemu przez większość społeczeństwa. Ich treść i forma świadczą o zrozumieniu oraz trafnym wskazaniu źródeł katastrofalnej sytuacji Rumunii. Społeczeństwo rumuńskie było gotowe odrzucić ówczesny ustrój społeczny, gospodarczy i polityczny

Autor: Agnieszka Kastory, Uniwersytet Jagielloński, Wydziat Studiów Międzynarodowych i Politycznych, ul. Jabłonowskich 5, 31-114 Kraków, Polska, agnieszka.kastory@uj.edu.pl, Kraków, Polska, ORCID iD: https://orcid. org/0000-0003-1282-4878

Słowa kluczowe: Rumunia, Ambasada PRL w Bukareszcie, Vaclav Havel, Nicolae Ceauşescu, Mirea Dinescu, dysydenci

Keywords: Romania, Polish Embassy in Bucarest, Vaclav Havel, Nicolae Ceauşescu, Mircea Dinescu, dissidents

Balcanica Posnaniensia. Acta et studia, XXVII, Poznań 2020, Wydawnictwo Wydziału Historii UAM, pp. 151166, ISBN 978-83-66355-54-5, ISSN 0239-4278. Polish text with summaries in English and Polish.

doi.org/10.14746/bp.2020.27.10 


\section{WPROWADZENIE}

Václav Havel w swym eseju Siła bezsilnych napisanym w 1978 r. przedstawił komunistyczny system społeczno-polityczny ugruntowany pod koniec lat 70 . XX wieku jako zamknięty układ oparty na kłamstwie. Może on sprawnie funkcjonować jedynie, gdy wszyscy uczestnicy trwającej w nim gry pozorów zachowują obowiązujące reguły, a więc wierzą lub udają, że wierzą w kłamstwo, na którym układ się opiera. Dla własnego dobrobytu poświęcają etykę i moralność oraz zrzekają się odpowiedzialności za byt własny i innych. Trudno im jednak w tej sytuacji zachować poczucie własnej godności. Tu z pomocą przychodzi rządząca układem ideologia, która dostarcza wygodne usprawiedliwienie dla tolerowania zakłamania. Ten zamknięty i wydawałoby się doskonały układ, łatwo jednak ulega rozszczelnieniu. Wystarczy odrzucić pozory i zwrócić się ku prawdzie, by zagrozić samym podstawom jego istnienia. $\mathrm{Z}$ tego powodu osoby, które zdecydowały się zaprzeczyć obowiązującym regułom, spotykają się z natychmiastowymi represjami i jest to naturalna reakcja samoobronna układu, nieustannie zagrożonego ujawnieniem prawdy. Do tego rozsadzają go napięcia wynikające z rozbieżności pomiędzy realizowanymi celami zdefiniowanymi przez obowiązującą ideologię a rzeczywistymi potrzebami ludzi, realizującymi swe życiowe potrzeby. W tym sensie obrona praw jednostki natychmiast staje się wyrazem sprzeciwu wobec systemu, podobnie jak postawa legalizmu, polegająca na odwoływaniu się do istniejących reguł prawnych. Osoby jawnie chcące bronić praw człowieka uzyskują miano odszczepieńców - dysydentów. Ich odosobnione wystąpienia, często spektakularne, są odnotowywane zarówno przez władze, jak i obserwatorów zagranicznych. Jednak dla układu największym zagrożeniem jest nie tyle jednostkowe, co powszechne dążenie do życia w prawdzie, odrzucenie fikcyjnej rzeczywistości i narastanie buntu przeciw manipulacji ${ }^{1}$.

W tym samym czasie, gdy Havel pisał swój tekst, w Rumunii następował zwrot ku zaostrzeniu kontroli społecznej i umocnieniu ideologicznych podstaw osobistej dyktatury prezydenta Nicolae Ceauşescu. Temu procesowi towarzyszyła degradacja sytuacji gospodarczej państwa, dotkniętego dodatkowo międzynarodową izolacją. W sierpniu 1977 r. przeciw pogarszaniu się warunków pracy zaprotestowali górnicy z Doliny Jiu. W kolejnych latach kryzys rumuńskiej gospodarki pogłębiał się prowadząc do reglamentacji żywości, energii cieplnej i elektrycznej. Lokalne lub indywidualne protesty nie odnosiły skutku. Władze bez trudu zdusiły listopadowy strajk robotników Braszowa w 1987 r. $^{2}$

Przemiany w radzieckim bloku związane z polityką Michaiła Gorbaczowa zostały przez rumuńskie kierownictwo odrzucone. Ceauşescu wykluczał jakiekolwiek re-

1 V. Havel, Sita bezsilnych, thum, Agnieszka Holland, w: Vaclav Havel, Sita bezsilnych i inne eseje, Warszawa 2011, s. 87-158.

2 Szerzej o tym, A. Burakowski, Geniusz Karpat. Dyktatura Nicolae Ceauşescu 1965-1989, Warszawa 2008, s. 214-215, 313. 
formy rynkowe w gospodarce, przystąpił natomiast do realizacji absurdalnego w ówczesnej sytuacji projektu systematyzacji wsi, mogącego mieć katastrofalne skutki, jeśli chodzi o produkcję rolną Rumunii ${ }^{3}$. Stanął też na gruncie niezbywalnej i niepodzielnej władzy partii komunistycznej, co wykluczało jakikolwiek kompromis z opozycją, gdyby taka powstała ${ }^{4}$.

Jednak w Rumunii w 1989 r. nie istniała zorganizowana opozycja, a ruch dysydencki był postrzegany jako bardzo słaby. Pracownicy polskiej ambasady w Bukareszcie wykluczali raczej możliwość jakichkolwiek zmian politycznych w Rumunii ${ }^{5}$. Wybuch protestów w grudniu 1989 r., które w przeciągu niespełna dwóch tygodni (od 15 do 25 grudnia) doprowadziły do obalenia i śmierci Ceauşescu musiał zaskakiwać. Można je jednak wytłumaczyć sięgając do koncepcji Václava Havla.

\section{PRZEJAWY SPRZECIWU WOBEC POLITYKI NICOLAE CEAUŞESCU W 1989 R. W ŚWIETLE OBSERWACJI POLSKIEJ AMBASADY W BUKARESZCIE}

Od 19 maja 1988 r. do 29 lipca 1990 r. ambasadorem Polski w Rumunii był Jerzy Woźniak. W 1989 r. ambasada przekazywała do Warszawy kwartalne raporty w formie całościowych notatek dotyczących Rumunii. Informowano w nich o sytuacji społeczno-politycznej, gospodarczej, polityce zagranicznej i sytuacji międzynarodowej oraz nastrojach społecznych. W 1989 r. raporty podpisywali Roland Aleksandrowicz, M. Szczerski, Łukasz Szymański i niektóre sygnowała dodatkowo Maria Włodarczyk. Wszystkie donosiły o pogarszaniu się społecznych nastrojów i zawierały przykłady pojedynczych protestów: wyrażony w formie listu do prezydenta Nicolae Ceauşescu protest poety Dana Dieşliu przeciw wyburzaniu wsi w procesie systematyzacji; rozrzucenie ulotek wrogich reżimowi w listopadzie 1988 r. w rocznicę wydarzeń

3 Projekt opracowany w 1986 r. miał doprowadzić do zbliżenia poziomu życia we wsi i w miastach oraz nasycić równomiernie państwo zakładami przemysłowymi, opartymi na lokalnych surowcach. Celem było zahamowanie odpływu ludności wiejskiej do miast, i zwiększenie napływu ludności miejskiej na wieś. Wzniesiono dwie wzorcowe wsie w Teremea Mare i Snagow. W zwartym systemie zabudowy powstały dwu i trzykondygnacyjne budynki mogące pomieścić cztery do sześciu rodzin w mieszkaniach o powierzchni średnio od 45 do $60 \mathrm{~m}^{2}$. Mieszkania miały wspólne umywalnie, toalety zlokalizowane na zewnątrz, piece na węgiel i drewno. Nie zaopatrzono ich w centralne ogrzewanie i ciepłą wodę. Do budynków mieszkalnych przylegały działki o powierzchni $300 \mathrm{~m}^{2}$. Plan przewidywał utworzenie 550 wsi miejskiego typu i 2000 usystematyzowanych gmin, zaopatrzonych w kompleksy kulturalno-oświatowe, Oficjalna prezentacja programu systematyzacji terytorium SRR z dnia 15.09.1989, opracowała M. Mazińska, Archiwum Ministerstwa Spraw Zagranicznych w Warszawie, [dalej: AMSZ], nr nabytku 37/93, [dalej: nr n.37/93], wiązka 2 [dalej: w. 2], teczka Rumunia [dalej: t. R.], s. 5; Notatka na temat systematyzacji wsi na obecnym etapie. AMSZ, nr n. 37/93, w. 2., t. R., s. 2.

4 Sytuacja wewnętrzna Rumunii w II kwartale 1989 r., AMSZ, nr n. 37/93, w. 2., t. R. s. 36; tamże, Notatka informacyjna z września 1989 r. o sytuacji w Rumunii w III kwartale 1989 r., s. 26.

5 Notatka w sprawie M. Dinescu i nastrojów opozycyjnych w Rumunii z 9.12.1989, AMSZ, nr. n. 37/93, w. 2., t. R. s. 42 . 
w Braszowie; samospalenie w lutym 1989 r. mieszkańca Braszowa. Brak zorganizowanych form protestu pracownicy ambasady thumaczyli nieustającymi represjami ${ }^{6}$.

Ambasada przesłała też do Warszawy list sześciu byłych wysokich funkcjonariuszy partyjnych do prezydenta Ceauşescu, podany do publicznej wiadomości 10 marca 1989 r., a 14 marca 1989 r. przekazany Radiu Wolna Europa ${ }^{7}$. Jego autorzy występowali w obronie idei socjalistycznej, którą ich zdaniem Ceauşescu dyskredytował, pogrążając Rumunię w izolacji międzynarodowej. Zarzucali mu złamanie postanowień Aktu Końcowego KBWE i rumuńskiej konstytucji, która przestała określać jakikolwiek porządek prawny w Rumunii. Za najbardziej jaskrawe przykłady naruszeń konstytucji i porządku prawnego wskazywali projekt systematyzacji; zakaz kontaktowania się z cudzoziemcami, realizowany w oparciu o dekret, którego nie przyjęło żadne ciało ustawodawcze, i którego nie podano do publicznej wiadomości; naruszenie przepisów budowalnych przy wznoszeniu w Bukareszcie centrum administracyjnego i zatajenie kosztów tej inwestycji; wykorzystywanie służby bezpieczeństwa powołanej do obrony „socjalistycznego porządku” w celu prześladowania robotników i osób kierujących petycje do władz; zmuszanie robotników do pracy w niedziele; kontrolę korespondencji i rozmów telefonicznych. Obnażali także niegospodarność, załamanie planowania gospodarczego, bałagan i brak konsekwencji w polityce rolnej. Piętnowali systematyzację jako projekt szkodliwy z gospodarczego punktu widzenia, sprzeczny z humanitaryzmem i zdrowym rozsądkiem. Alarmowali z powodu masowych wyjazdów z Rumunii Węgrów, Żydów i Niemców. Z niepokojem odnotowywali utratę amerykańskiej klauzuli najwyższego uprzywilejowania. Wzywali Ceauşescu do bezzwłocznego zaniechania systematyzacji wsi, przywrócenia obywatelom ich konstytucyjnych praw; zaniechania dalszego eksportu żywności, zagrażającego biologicznemu istnieniu rumuńskiego narodu ${ }^{8}$.

Władze nie ośmieliły się podjąć spektakularnych represji wobec autorów listu, ale poddały ich ścisłemu nadzorowi i izolacji. Jednak w lipcu 1989 r. został skazany na karę śmierci przybrany syn Grigore Răceanu, Mircea, pracownik Ministerstwa Spraw Zagranicznych ${ }^{9}$.

${ }^{6}$ Sytuacja w Rumunii w pierwszym kwartale 1989 r., AMSZ nr. n. 37/93, w. 2., t. R. s. 99-100; Pavel Câmpeanu, Ceauşescu, Warszawa 2004, s. 534.

7 List podpisali: Gheorghe Apostol, były członek Biura Politycznego i przewodniczący Związków Zawodowych, Aleksandru Bârlădeanu były członek Biura Politycznego i Przewodniczący Komitetu Planowania, Corneliu Mănescu, były minister spraw zagranicznych i przewodniczący Zgromadzenia Ogólnego ONZ, Constantin Pârvulescu, członek założyciel partii komunistycznej, Grigore Răceanu, weteran partii komunistycznej, Silviu Brucan, były pełniący obowiązki redaktora pisma „Scintea”. O genezie jego powstania pisze A. Burakowski, Geniusz Karpat. Dyktatura Nicolae Ceauşescu 1965-1989, Warszawa 2008, s. 335-336; treść listu podaje też P. Câmpeanu, op. cit., s. 528-531; Nicolae Păun, La chute du Mur de Berlin, symboles et action en Roumanie, s. 4/15-5/15, https://books.openedition.or/cirac/ 265\#text, (dostęp 12.09.2020 r.).

8 List byłych funkcjonariuszy partyjnych do Prezydenta Nicolae Ceauşescu, AMSZ, nr. n. 37/93, w. 2., t. R. s. 89-91.

9 Sytuacja w Rumunii w pierwszym kwartale 1989 r., AMSZ nr. n. 37/93, w. 2., t. R., s. 100; M. Răceanu zastępca Dyrektora Wydziału.05.(obie Ameryki) został aresztowany 31.01.1989, oskar- 
Polska ambasada przekazała również do Warszawy rzekomy wywiad, który 13 kwietnia 1989 r. przeprowadził sam ze sobą emerytowany inżynier Nicolae Stancescu, po czym dostarczył go ambasadom państw zachodnich z intencją, by ukazał się w czasopiśmie „Agora”, wydawanym w Filadelfii. Był to alternatywny przegląd kulturalny publikowany po rumuńsku. Jego honorowym przewodniczącym był Eugene Ionesco, a w składzie redakcyjnym zasiadał Kazimierz Brandys.

Nicolae Stancescu dwukrotnie w 1972, a następnie w 1979 r. zwracał się listownie do Nicolae Ceauşescu, prezentując sposoby uzdrowienia rumuńskiej gospodarki. W latach 80. kilkakrotnie występował z inicjatywą powołania zespołu ekspertów do spraw reformy. Wykorzystywał wszelkie legalne możliwości, by głosić swoje poglądy. Ceauşescu nigdy nie zareagował na jego listy. Natomiast zrobiła to rumuńska prokuratura, zapraszając Stancescu do siedziby Prokuratury Generalnej w charakterze świadka, jak się okazało, fikcyjnego procesu. Po przybyciu Stancescu został pobity, a następnie przewieziony do więzienia, gdzie pobito go ponownie. W sumie był dwukrotnie aresztowany, a w jego sprawie interweniowała ambasada $\mathrm{RFN}^{10}$.

Stancescu głosił konieczność przeprowadzenia w Rumunii reform politycznych, gospodarczych, społecznych i duchowych. Uważał, że nadanie rumuńskiej gospodarce mieszanego charakteru i dopuszczenie sektora prywatnego, pozwoliłoby osiągnąć równowagę popytu i podaży. Reformy były jego zdaniem tak niezbędne, że mogli się im sprzeciwiać jedynie spekulanci różnej maści, oszuści z nomenklatury, osoby niekompetentne, uprzywilejowane i wygodne. Krytykował projekt systematyzacji, jako nieefektywny i opracował własny plan modernizacji wsi polegający na utworzeniu w każdym województwie dwóch lub trzech gminnych centrów ze wszystkimi urządzeniami podnoszącymi jakość życia, które przyciągałyby ludność z przeznaczonych do likwidacji wsi ${ }^{11}$.

W sferze politycznej wskazywał na destrukcyjny charakter systemu jednopartyjnego, który spowodował podział społeczeństwa na uprzywilejowaną grupę funkcjonariuszy partyjnych i na ludzi pracy, będących przedmiotem represji. Poza tym sprzyjał nadużyciom, korupcji, nieuczciwości, prowadząc ostatecznie do totalitarnego charakteru władzy. Zdaniem Stancescu należało wyłonić drogą wolnych wyborów legalne kierownictwo, zdolne zapewnić zasady demokratyczne i naprawić gospodarkę. Przywrócenie wolności słowa, zwiększenie roli środków masowego przekazu, instytucji kultury, aktywizacja inteligencji pozwoliłyby, jego zdaniem, uzdrowić życie społeczne, a przede wszystkim pokonać wszechobecną apatię: Demokracja jest nam potrzebna jak powietrze, wolność jak chleb i reformy jak ogieńn ${ }^{12}$. Wykazywał na przy-

żony o zdradę stanu i skazany 21.07.1989 na karę śmierci. Po interwencji prezydenta USA G. Busha, 19.09.1989 wyrok złagodzono do 20 lat więzienia, A. Burakowski, op. cit., s. 336.

10 Wywiad z Nicolae Stancescu, [dalej: Wywiad z N. Stancescu], AMSZ, nr n. 37/93, w. 2., t. R., s. 76. Notatka w sprawie dalszych wystąpień opozycyjnych w Rumunii, 18.05.1989, AMSZ, nr n. 37/93, w. 2., t. R., s. 67.

11 Wywiad z N. Stancescu, s. 77, 81.

12 Wywiad z N. Stancescu, s. 79. 
kładzie represji, jakim sam był poddawany, że w Rumunii wbrew konstytucji i międzynarodowym konwencjom prawa człowieka były ograniczane lub nie były przestrzegane. Jego własna korespondencja podlegała kontroli. Z tego powodu jego list do prezydenta USA George'a Busha nigdy do niego nie dotarł, a kosztów przesyłki poczta mu nie zwróciła. Powszechny brak praworządności Stancescu kwitował z prostotą: Jak tak siedzę, myśle i stwierdzam, że ja jako obywatel, nie mogę znaleźć niczego do czego mam prawo ${ }^{13}$.

Stancescu, chociaż uważał, że to Ceauşescu powinien zainicjować i przeprowadzić reformy oraz skontrolować osoby, które łamały prawa człowieka, to jednak wzywał do interwencji w obronie praw Rumunów odpowiednie agendy ONZ ${ }^{14}$.

Stancescu w przeciwieństwie do sygnatariuszy Listu sześciu, którzy bronili założeń „socjalizmu”, proponował reformy, które zagrażały jego istnieniu, obnażał przepaść między porządkiem ideologicznym, a potrzebami codziennego życia, opowiadając się za przywróceniem „ludzkiego porządku”. Bunt jego zdrowego rozsądku był całkowicie jawny, Stancescu podał w wywiadzie swój domowy adres ${ }^{15}$.

W czerwcu 1989 r. zachodnie środki masowego przekazu upowszechniły list otwarty Dumitru Mazilu, specjalnego sprawozdawcy Komisji Praw Człowieka ONZ, skierowany do sekretarza generalnego ONZ Javiera Pereza de Cuillara i przewodniczącego Komisji Praw Człowieka prof. Marca Bossuyta z dołączonym Sprawozdaniem na temat praw czlowieka i młodzieży - spojrzenie na sprawę rumuńska. Mazilu pracował nad Sprawozdaniem od 1985 r. Nie zdołał go jednak dostarczyć Komisji Praw Człowieka, ze względu na odmowę wydania paszportu, zamknięcie w areszcie domowym i systematyczną konfiskatę jego korespondencji z ONZ ${ }^{16}$. W 1989 r. postanowił uzupełnić i ujawnić swój raport dostarczając go do przedstawicielstw obcych państw w Bukareszcie, w tym do polskiej ambasady. W lipcu 1989 r. jego Sprawozdanie dotarło do Genewy i zostało upowszechnione przez Radio Wolna Europa ${ }^{17}$.

W Sprawozdaniu Mazilu oskarżył Ceauşescu, że świadomie i z premedytacją naruszył wszelkie zasady i prawa chroniące człowieka, a rumuńskie władze pogardzają ludźmi i odmawiają im najbardziej podstawowych praw, w tym dostępu do żywności,

13 Wywiad z N. Stancescu, s. 80.

14 Wywiad z N. Stancescu, s. 77-80.

15 Wywiad z N. Stancescu, s. 80, 83.

16 List ambasadora Jerzego Woźniaka do tow. Ryszarda Korczewskiego, Dyrektora Departamentu Polityki Kulturalnej i Naukowej MSZ z 21.07.1989, [dalej: List J. Woźniaka z 21.07.1989], AMSZ, nr n. 37/93, w. 2., t. R.w.2, s. 18, 20; D. Mazilu, Sprawozdanie na temat Praw człowieka i młodzieży-spojrzenie na sprawę rumuńska, [dalej: D. Mazilu, Sprawozdanie], AMSZ, nr n. 37/93, w. 2., t. R. s. 30. Komisja Praw Człowieka ONZ powstała 16.02.1946 r. w oparciu o Kartę Narodów Zjednoczonych. Komisja od 1967 r. wskazywała w razie potrzeby specjalnego sprawozdawcę do referowania konkretnego problemu, szerzej o tym: J.B. Marie, Praktyka Komisji Praw człowieka ONZ w związu z naruszeniami praw człowieka, „Ruch Prawniczy, Ekonomiczny i Socjologiczny”, t. 43, nr 1, 1981, s. 1, 116 i inne, https://repo zytorium.amu.edu.pl/bitstream/10593/21054/1/009\%20JEAN-BERNARD\%20MARIE\%20RPEiS\%20 43\%281\%29\%2C\%201981.pdf [dostęp: 25.08.2020].

17 A. Burakowski, op. cit., s. 338-339. 
ciepła, światła, opieki macierzyńskiej. Mazilu wskazywał, że powodem tej „nieprawdopodobnej sytuacji” było nadużywanie władzy, brak jakiejkolwiek formy demokracji, policyjny terror, a w dziedzinie gospodarczej niekompetencja i błędy. Donosił o rosnącej liczbie przypadków okrutnego traktowania, a nawet potajemnego unicestwiania młodych ludzi jawnie demonstrujących postawę opozycyjną. Stwierdzał, że po strajkach w Dolinie Jiu w 1977 r. i w Braszowie w 1987 r. zawieszono wszystkie konstytucyjne prawa wprowadzając praktycznie stan oblężenia. Obywatele pozbawieni swobody osobistej, nietykalności domu i korespondencji, wtrącani do więzień lub szpitali psychiatrycznych byli bezbronni wobec wszechwładzy tajnej policji. Wyrażanie odmiennej od oficjalnej wersji opinii było traktowane jako zdrada sprawy socjalizmu i podlegało karze. Zdaniem Mazilu represje nasiliły się po ujawnieniu Listu sześciu i protestach znanych pisarzy. Twierdził, że w stosunku do co najmniej 47000 osób zastosowano nadzór policyjny lub inne represje ${ }^{18}$.

Mazilu dostrzegał poważne zagrożenie dla rozwoju dzieci i młodzieży, ze względu na pogarszające się od 1980 r. warunki życia i brak troski o dzieci: Dziecko poczęte jest niczym $i$ traktowane jest jak kociak ${ }^{19}$. Pisał, że wiele matek niedożywionych i wyziębionych nie mogło z braku pokarmu karmić piersią. Szacował, że nieogrzewane domy i szpitale, brak leków i zła opieka medyczna powodowały wzrost umieralności niemowląt do $19 \%$. Władze, by ukryć ten fakt nie rejestrowały dzieci od razu po urodzeniu. Rumuńska młodzież pozbawiona kontaktu ze światem zewnętrznym była gorzej wykształcona, dotykało ją też w dużym stopniu bezrobocie. Mazilu twierdził, że w 1983 r. bezrobocie sięgało 300 tys., a w 1989 r. 540 tysięcy ${ }^{20}$. Szacował, że przystąpienie do systematyzacji wsi doprowadziło do samobójstwa nawet 119 osób, a od 1985 r. za wyrażanie własnej opinii ucierpiało nawet 4000 osób ${ }^{21}$.

Wymieniłznanych mu dysydentów, w tym pisarzy: Dana Petrescu, Mirceę Dinescu, Dana Deşliu; inżynierów: Radu Filipescu, Nicu Stancescu, Gabriela Andreescu; naukowców i nauczycieli akademickich, Mihai Boteza, Marianę Celac, Doinę Cornea; sygnatariuszy Listu sześciu; dziennikarzy: Petre Mihai Băcanu, Antona Uncu (obaj z „România Libera”), Mihai Creangă (z „România Pitorească”) i drukarza Alexandru Chivoiu. Twierdził, że za obronę prawa do własnych przekonań został umieszczony w więzieniu psychiatrycznym Nestor Corneliu Popescu; za próbę utworzenia związku zawodowego uwięziono Mihai Torba i Mariana Brincoveanu, a Gheorghe Ursu, za upowszechnianie analiz dotyczących sytuacji Rumunii został zamordowany ${ }^{22}$.

18 List J. Woźniaka z 21.07.1989, s. 20-21.; D. Mazilu, Sprawozdanie, s. 30-31, 34.

19 D. Mazilu, Sprawozdanie, s. 31.

20 D. Mazilu, Sprawozdanie, s. 31, 33.

21 List J. Woźniaka z 21.07.1989, s. 20.

22 D. Mazilu, Sprawozdanie, s. 33. Inż. R. Filipescu za rozdawanie ulotek w 1983 r. został skazany na 10 lat więzienia; G. Andreescu, fizyk, wielokrotnie aresztowany, w maju 1989 r. rozpoczął strajk głodowy; inż. Gh. Ursu zmarł w listopadzie 1985 r. na skutek tortur, T. Kunze, Ceauşescu. Piekto na ziemi, Warszawa 2016, s. 375. Osoby te wspomina także P. Câmpeanu, op. cit., s. 533. 
Mazilu donosił, że przy nielegalnych próbach przekroczenia granicy straciło życie około 400 osób, a na skutek polityki przymusowej asymilacji od 1983 r. co najmniej 90 tys. Węgrów, Żydów i Niemców opuściło Rumunię. Zaznaczył jednak, że rumuńskie społeczeństwo potępiało uprawniany przez władze handel mniejszościami, podobnie jak handel rumuńskimi dziećmi ${ }^{23}$.

Swój raport Mazilu kończył wzywając ONZ, by zmusiła rumuński rząd do przeprowadzania wolnych wyborów, rezygnacji z projektu systematyzacji, poprawienia zaopatrzenia w żywność, przywrócenia obywatelom konstytucyjnych praw, przeprowadzenia dochodzenia w sprawie torturowania i poniżającego traktowania protestujących w Braszowie robotników ${ }^{24}$.

Polska ambasada przechowała również list z 17 października 1989 r. napisany do Ceauşescu przez Leona Nicu, trzydziestoczteroletniego młodszego inżyniera mechanika, absolwenta studiów wieczorowych, ojca co najmniej jednego dziecka. Nicu swój List otwarty do Prezydenta i Narodu Rumuńskiego uzupełnił pełnym adresem zamieszkania ${ }^{25}$.

List jest zbudowany z szeregu pytań, na które Nicu sam odpowiada, starając się obnażyć zakłamanie całego systemu. Stwierdzał w nim, że Ceauşescu rządzi Rumunią wraz z wąską kasta oddanych mu ludzi, bez jakiejkolwiek legitymizacji ze strony narodu lub partii. Rządząca kasta zachowuje lojalność wobec prezydenta, jedynie dlatego, że czerpie z tego materiale korzyści (dostęp do żłobu), zaś szeregowi członkowie partii nie mają żadnego wpływu na decyzje, chociaż Ceauşescu formalnie działa w ich imieniu. Reprezentację narodu, czyli Wielkie Zgromadzenie Narodowe, nazwał zgromadzeniem owiec, którymi można dowolnie manipulować. Zarzucił Ceauşescu, że rządzi w imię ideałów, które nigdy nie staną się rzeczywistością i wedle praw, które narzucił Rumunom, ale sam ich nie przestrzegał. Za istniejący stan rzeczy winił też samych Rumunów, zdezorientowanych, zubożałych i głodnych, którzy ze strachu i głupoty oklaskiwali prezydenta, nawet gdy ten twierdził, że za dużo jedzą lub podejmował niekorzystne dla nich decyzje. Rumunom jego zdaniem brakowało świadomości, że milicjanci i żołnierze nie zastąpią ich w pracy, ani nie aresztują wszystkich, ponieważ ktoś musi pracować, by realizować eksport, dzięki któremu Ceauşescu gromadził dewizy potrzebne do realizacji wszystkich jego dzieł w kraju i za granicą ${ }^{26}$.

Nicu stwierdzał, że Ceauşcescu uczynił z Rumunów niewolników, odebrał im prawo do wyrażania opinii, zrobił wszystko, by życie ludzi było jak najgorsze, zabierając jedzenie, ciepło, światło, benzynę. Skalę panującego bezprawia ukazywał porównując istniejącą sytuację z rzeczywistością polityczną okresu międzywojennego,

23 D. Mazilu, Sprawozdanie, s. 34; list J. Woźniaka z 21.07.1989, s. 21.

24 List J. Woźniaka z 21.07.1989, s. 22.

25 Leon Nicu, List otwarty do prezydenta Nicolae Ceauşescu i Narodu Rumuńskiego [dalej: L. Nicu, List otwarty], tłum. M. Mazińska, AMSZ, nr n. 37/93, w. 2., t. R. s. 56, 62.

26 L. Nicu, List otwarty, s. 56-58. 
w której Ceauşescu, jako walczący i prześladowany komunista zachował jednak prawo do głoszenia swych poglądów i uczciwego procesu:

Miniony reżim nie wykończył Pana, nie spowodował, aby przejechał Pana samochód lub aby wyrzucono Pana z wysokiego piętra, nie wsadził Pana do czubków, nie katował i nie torturował, a także nie otruł - gdyby było inaczej nie dożyłby Pan pięknego wieku 70 lat na czele nas wszystkich ${ }^{27}$.

Wiele miejsca Nicu poświęcił hipokryzji Ceauşescu, który wzywając: wierzcie i nie sprawdzajcie, represjonował wszystkich, którzy próbowali zweryfikować realizację złożonych przez niego obietnic. Nicu przypomniał Ceauşescu, jak starając się o pokojową nagrodę Nobla organizował sobie wiece poparcia, a potępił rzeczywiście spontaniczną manifestację w Braszowie. Wytykał prezydentowi, że głosząc nowy, pokojowy model w stosunkach międzynarodowych, wtrącał się w sprawy Węgier, domagał się interwencji Układu Warszawskiego w Polsce i używał siły wobec własnego $\operatorname{narodu}^{28}$.

Nicu domagał się podobnie jak Mazilu przeprowadzenia powszechnych wyborów prezydenckich i był gotowy zgłosić własną kandydaturę. Zapewniał, że jego poglądy nie były wytworem zewnętrznej propagandy, ale produktem rumuńskiego socjalizmu. On sam wychowany na kłamstwach wyniesionych ze szkoły, demaskował je po kolei w swym życiu. Dlatego był pewny, że żyje w kraju, kierowanym przez bezsilna $i$ słaba partię, która boi się pierwszego z brzegu robotnika dochodzacego swoich praw, a nawet niewinnej maszyny do pisania, że skala wartości stoi na głowie i że obecny rzad kieruje się mottem: niszczcie szarego człowieka i prawdę ${ }^{29}$.

\section{FERMENT W ZWIĄZKU PISARZY RUMUŃSKICH}

Ambasada Polski w Bukareszcie śledziła uważnie protesty rumuńskich pisarzy, kierowane przeważnie do kierownictwa Związku Pisarzy Rumuńskich [dalej: Związku Pisarzy]. Dzieje relacji między pisarzami a komunistycznym reżimem w Rumunii ukazał w skrócie Mircea Dinescu w eseju zatytułowanym Mamut i literatura. Wedle jego literackiej wizji, w latach 50. pisarze, którzy zdecydowali się odegrać rolę zaufanych pomocników partii, czy jak to określił podpisali pakt z diabłem, należeli do kategorii ludzi uprzywilejowanych. Ich udziałem były miejsca w luksusowym domu pracy twórczej oraz wysokie honoraria. Za opublikowanie na pierwszej stronie partyjnego dziennika jednego wiersza, można było nabyć palto z angielskiej wełny i jeść przez miesiąc w najlepszej bukaresztańskiej restauracji. Jak pisał Dinescu: W taki oto sposób weszli na arenę pierwsi partyjni milionerzy z szeregów pisarskich i od tego

27 L. Nicu, List otwarty, s. 59.

28 L. Nicu, List otwarty, s. 60-61.

29 L. Nicu, List otwarty, s. 66. 
czasu aż do dzisiaj tego typu aktywiści pióra, zgarbieni od nadmiaru przywilejów, przewodza pisarskiej braci i sa jej rzecznikami ${ }^{30}$.

W latach 60. XX w. władze, poszukując większej akceptacji społecznej, złagodziły represje. Nowa tendencja w polityce wiązała się ze sporem, jaki toczył Gheorghe Gheorgiu-Dej z Nikitą Chruszczowem o zasady współpracy w ramach RWPG. W 1963 r. została ogłoszona amnestia, a Rumunia otworzyła się na kontakty z Chinami i państwami zachodnioeuropejskimi. Politykę tę kontynuował początkowo następca Deja na stanowisku sekretarza generalnego partii Nicolae Ceauşescu. Kontrola cenzury uległa złagodzeniu, większa swoboda przyczyniła się do rozwoju nauki, kultury i literatury ${ }^{31}$. W tej sytuacji, jak stwierdzał Dinescu wielu twórców zdawałoby się na zawsze pogrzebanych pod śmieciem przeciętności mogła zaistnieć na rynku wydawniczym ${ }^{32}$.

Jednak w latach 70. Ceauşescu skupił się na umacnianiu własnej pozycji w partii i w państwie. Przebudował Komitet Centralny Rumuńskiej Partii Komunistycznej, wprowadzając do niego oddanych sobie towarzyszy. W 1974 r. został wybrany przez Zgromadzenie Narodowe prezydentem Rumunii. Pod wpływem doświadczeń chińskiej rewolucji kulturalnej i praktyk rodem z Korei Północnej, wznosił swój osobisty kult, czemu towarzyszyła tendencja do ograniczania swobody środowisk twórczych. Nowy kierunek w polityce Ceauşescu przedstawił na posiedzeniu Komitetu Centralnego partii 6 lipca 1971 r. Wezwał do zwiększenia ideologicznej kontroli nad rumuńskimi środowiskami twórczymi, w pierwszej kolejności pisarzami i dziennikarzami. W grudniu 1971 r. weszły w życie przepisy zabraniające publikowania za granicą tekstów godzących w interes Rumunii. Kontroli poddano nie tylko twórczość, ale prywatne życie pisarzy ${ }^{33}$.

Na fali nowej polityki władz doszło do rozłamu w literackim środowisku. Twórcy związani z tygodnikiem „Săptămâna”, wyrażający poparcie zarówno komunizmu,jak i rumuńskiego nacjonalizmu zaproponowali 18 września 1980 r. zastąpienie Związku Pisarzy Związkiem Pisarzy Komunistów. Ceauşescu spotkał się 13 października z pisarzami i odrzucił postulaty środowiska tygodnika „Săptămâna”. Zgodził się także na rozwiązanie organizacji partyjnej przy Związku Pisarzy. Jednocześnie jednak zapowiedział obniżenie wynagrodzenia zrzeszonych w nim literatów. Rok później, Konferencja Związku Pisarzy (1-4 lipca 1981 r.), stała się widownią antykomunistycznej demonstracji. W tej sytuacji Komitet Centralny RPK wysunął do funkcji przewodniczącego Związku własnego kandydata, Dumitru Radu Popescu, który przy braku zdecydowanego kontrkandydata, objął to ważne stanowisko ${ }^{34}$.

30 Mircea Dinescu, Mamut i literatura, tłum. Kazimierz Jurczak [dalej: M. Dinescu, Mamut i literatura], AMSZ, nr. n. 37/93, w. 2., t. R., s. 54.

31 M. Willaume, op. cit., s. 208, 215.

32 M. Dinescu, Mamut i literatura, s. 55.

33 M. Willaume, op. cit., s. 225-227.

34 A. Burakowski, op. cit., s. 251-252. 
Dzięki trafnej nominacji władze zapewniły sobie nie tylko lojalność kierownictwa Związku Pisarzy, ale uczyniły z niego wygodne narzędzie dyscyplinowania i represjonowania literackiego środowiska. Popescu pełnił swoją funkcję do 1989 r., a od 1985 r. nie zwoływał Rady Kierowniczej, podejmując decyzje samodzielnie ${ }^{35}$.

Mircea Dinescu w eseju Mamut i literatura zarzucał nowemu zarządowi, że przekształcił Związek Pisarzy w formę spółdzielni produkcyjnej, której podstawowym towarem była alienacja. Temu przeobrażeniu towarzyszyła materialna, a zdaniem Dinescu także duchowa degradacja pisarskiego środowiska. Poeta stwierdzał cynicznie, że cena jednego wiersza drastycznie się zmniejszyła (do ceny jednego kotleta $\mathrm{w}$ restauracji, ale już bez chleba); zniknęły fotografie autorów z okładek ich własnych tomików; zaostrzono cenzurę, zmarginalizowano twórców rzeczywiście utalentowanych na rzecz amatorskiej szarańczy i oficjalnych cymbalistów $w^{36}$.

Sam Mircea Dinescu w 1989 r. był już uznanym poetą, autorem ośmiu tomów poezji wydanych w języku rumuńskim i przetłumaczonych na języki obce, laureatem czterech nagród Związku Pisarzy i jednej Akademii Rumuńskiej. Jego kłopoty rozpoczęły się latem 1988 r. od wizyty w Związku Radzieckim, a dokładniej w republikach bałtyckich, którą złożył na osobiste zaproszenie sekretarza Związku Pisarzy ZSRR. Dinescu nie bez trudu wyjechał i to nie w charakterze oficjalnym, lecz prywatnym. Goszcząc w Związku Radzieckim wypowiedział się entuzjastycznie na temat pieriestrojki i głasnosti w wywiadzie dla Radia Moskwa.

Po powrocie z ZSRR udał się do Berlina Zachodniego, gdzie w dniach od 14 do 18 września 1988 r. uczestniczył w konferencji na temat literatury w berlińskiej Akademii Sztuk. Wygłosił tam referat o kondycji pisarza, zatytułowany Chleb i cyrk (Pîinea şi circus $)^{37}$. Do tego zdecydował się wydać w Amsterdamie tom wierszy zatytułowany Śmierć czyta gazetę. Manuskrypt zaakceptowało wprawdzie wydawnictwo Cartea Romanesca, jednak nie uzyskało zgody cenzury, Rady Kultury i Wychowania Socjalistycznego ${ }^{38}$. Na dodatek 17 marca 1989 r. francuska „Liberation” opublikowała wywiad, który Dinescu udzielił jej w grudniu 1988 r. Poeta krytykował w nim rumuńskie władze, które zamiast pieriestrojki i głasnosti zaoferowały Rumunom maoizm i północnokoreański faraonizm, przekształcając Rumunię nie tyle w tacińska

35 Notatka w sprawie dalszych wystąpień opozycyjnych w Rumunii z 18.05.1989 z dołączonym listem Mircei Dinescu do Przewodniczącego Związku Pisarzy z 1989 r., [dalej: List M. Dinescu z 1989 r.], AMSZ, nr. n. 37/93, w. 2., t. R., s. 74.

36 M. Dinescu, Mamut i literatura, s. 55.

37 Wystąpienie M. Dinescu zostało opublikowane w grudniu 1988 r. w „Sprache im Technischen Zeitalter"; P. Paţilea (Crângan), The Political discourse as ideological subversive act in the Romanian totalitarian age. Mircea Dinescu's case, „Procedia. Social and Behavioral Sciences” 2012, nr 63, s. 101. Tłumaczenie tytułu wystąpienia M. Dinescu jako Chleb i cyrk zostało użyte przez ówczesnych tłumaczy: Kazimierza Jurczaka i Grzegorza Matusiewicza.

38 List M. Dinescu z 1989 r., s. 73; P. Paţilea, op. cit., s. 104. 
wyspę zagubiona w stowiańskim morzu, co w prawdziwą wyspę pogrążoną w egzystencjalnej izolacji, dużo głębszej, niż językowa ${ }^{39}$.

Dinescu już po powrocie z republik bałtyckich został objęty ścisłą i widoczną dla niego samego obserwacją, nasilającą się gdy tylko poeta opuszczał mieszkanie, lub oczekiwał wizyty gości, tak krajowych, jak i zagranicznych ${ }^{40}$. Inwigilację poety, polegającą na podsłuchiwaniu jego rozmów, prowadzono także w budynku Związku Pisarzy, o czym Dinescu poinformował przewodniczącego Popescu w niedatowanym, a napisanym zapewne w kwietniu 1989 r. liście. Podejrzenia Dinescu wzbudził talerz, na którym kelner zwyczajowo serwował chleb do obiadu w stołówce Związku Pisarzy. Po posiłku, który Dinescu spożył wspólnie z Danem Deşliu, ów talerz był pilnie poszukiwany w kuchni przez funkcjonariusza służby bezpieczeństwa, o czym personel stołówki dyskretnie poinformował obu poetów. Przy kolejnym wspólnym z Dinescu posiłku (14 marca 1989 r.), Deşliu schował podejrzany talerz do teczki, chcąc obejrzeć go w domu. Jednak po opuszczeniu lokalu, został brutalnie zaatakowany przez nieznanego sprawcę, który pozbawił go teczki, talerza i potencjalnego dowodu na istnienie podsłuchu. List Dinescu zawierający opis całej sytuacji, miał formę zarazem zabawnej i tragicznej opowieści, ale nie dotyczył jedynie incydentu z talerzem. Był w rzeczywistości zbeletryzowaną skargą na przyłączenie się Związku Pisarzy i osobiście przewodniczącego Popescu do represji stosowanych przez służbę bezpieczeństwa wobec pisarzy. 14 marca $1989 \mathrm{r}$. Popescu, powiadomił poetę o pozbawieniu go funkcji sekretarza redakcji pisma „România Literara”, ponieważ bez zezwolenia uczestniczył w przyjęciach wydawanych przez obce ambasady i przyjmował wizyty dziennikarzy, pisarzy i dyplomatów z krajów socjalistycznych i kapitalistycznych. W ten sposób czteroosobowa rodzina Dinescu (żona i dwoje dzieci), została pozbawiona środków do życia. Następnie Dinescu otrzymał zakaz wstępu do siedziby Związku Pisarzy, wyrzucono go z organizacji partyjnej i zastosowano areszt domowy ${ }^{41}$.

Sprawa Dinescu została nagłośniona dzięki zagranicznym rozgłośniom. Kilku pisarzy opodatkowało się na utrzymanie jego rodziny. Dan Deşliu, poturbowany w trakcie walki o talerz, wystosował list protestacyjny do Popescu, wyrażając oburzenie z powodu odkrycia podsłuchów w siedzibie Związku Pisarzy, a także pozbawienia pracy Dinescu i osadzenia go w areszcie domowym za, jak twierdził, udzielenie wywiadu dla „Liberation”42.

39 P. Câmpeanu, op. cit., s. 534; Notatka w sprawie Dinescu i nastrojów opozycyjnych w Rumunii z 9.12.1989, AMSZ, nr n. 37/93, w. 2., t.R., s. 42; P. Paţilea, op. cit., s. 101-102. Wywiad rozpowszechniło tego samego dnia Radio Wolna Europa w audycji Actualitatea culturală românească. Buletin de stiri17 martie 1989, Radio Europa Liberă Râmania, Istoria trăită, Sorin Şerb, 16 martie 2019, s. 2/8, https:// romania.europalibera.org/a/buletin-de-stiri-17-martie-1989/29824981.html, (dostęp 12.09.2020 r.).

40 List M. Dinescu z 1989 r., s. 72.

41 List M. Dinescu z 1989 r., s. 73; Notatka w sprawie Dinescu i nastrojów opozycyjnych w Rumunii z 9.12.1989, AMSZ, nr. n. 37/93, w. 2., t. R., s. 42; Buletin de ştiri 17 martie 1989..., s. 2/8.

42 Sytuacja w Rumunii w pierwszym kwartale 1989 r., AMSZ nr. n. 37/93, w. 2., t. R., s. 101; Notatka w sprawie dalszych wystąpień opozycyjnych w Rumunii, 18.05.1989, AMSZ, nr n.37/93, w. 2., 
W obronie Dinescu występowały kolejne osoby. Aurel Dragos Munteanu w liście z 8 kwietnia 1989 r. wezwał Dumitru Radu Popescu, by podjął działania na rzecz nie tylko Mircei Dinescu, Dana Deşliu, ale innych represjonowanych pisarzy. Przypominał, że zadaniem przewodniczącego była obrona praw pisarzy do swobody wypowiedzi, wolności i bezpieczeństwa fizycznego oraz moralnego. Zdaniem Munteanu, dopóki Mircea Dinescu i Dan Deşliu nie odzyskają pełnej swobody, a poetka Ana Blandiana swej pozycji w czasopismach i księgarniach, tak długo żaden pisarz rumuński nie powinien był chwytać za pióro ${ }^{43}$.

Pod koniec marca 1989 r. został wystosowany do Popescu list w obronie Dinescu i Deşliu oraz generalnie wolności działalności twórczej. Złożyli pod nim podpisy: Geo Bozga, Ştefan Augustin Doinaş, Dan Hăulică, Alexandru Paleologu, Octavian Paler, Andrei Pleşu, Mihai Şora, Alexandru Calinescu. List nie wywołał żadnej reakcji przewodniczącego poza zastosowaniem wobec jego sygnatariuszy zakazu publi$\mathrm{kacji}^{44}$.

Do zastosowanych wobec sygnatariuszy listu represji odniósł się 28 września 1989 r. Radu Enescu w liście otwartym do Popescu. Potępił w nim represje zastosowane wobec Dinescu, sygnatariuszy listu wystosowanego w jego obronie i Any Blandiany, którą objęto zakazem publikacji i zlikwidowano jej stałą rubrykę w „Romania Literara”. Zarzucał Popescu, że dążył do unicestwienia w osobie Dinescu, najlepszego poety Rumunii. Wyrzucił go na bruk zamiast szczycić się nim przed światem i wysunąć go do Nagrody Nobla. Piętnował pozbawienie możliwości publikowania eseistów i myślicieli na miarę europejską, umieszczenie na indeksie Ştefana Augustina Doinaşa, który mimo zasług dla literatury nie doczekał się opracowania swej twórczości. Jego rękopisy kurzyły się w szufladach wydawnictwa, natomiast Popescu zadbał o wydanie na swój temat trzech książek. Enescu stwierdzał szyderczo, że gdyby Mihai Eminescu żył w 1989 r., Popescu również jego umieściłby na liście niepożądanych szkodników ${ }^{45}$.

\footnotetext{
t. R., s. 67. Notatka w sprawie M. Dinescu i nastrojów opozycyjnych w Rumunii z 9.12.1989, AMSZ, nr n. 37/93, w. 2., t. R., s. 42.

43 Buletin de ştiri 17 martie 1989 ..s. 3/8; Notatka w sprawie dalszych wystąpień opozycyjnych w Rumunii 18.05.1989, AMSZ, nr. n. 37/93, w. 2., t. R., s. 67, 69-70; P. Câmpeanu, op. cit., s. 534. A.D. Munteanu, pisarz i reportażysta, współpracownik „Contemporanul”, „Romania Literara” i „Luceafărul” organu Związku Pisarzy, promującego młodych pisarzy. W 1988 r. wystąpił z RPK w proteście przeciw systematyzacji, został usunięty z pisma „Luceafărul” i umieszczony na czarnej liście, jako margines społeczny. Jak sam pisał, poddano go nadzorowi i pozbawiono służbowego telefonu, z którego, nie mógł dzwonić, a jedynie odbierać obraźliwe w stosunku do siebie rozmowy. Odmówiono mu też wydania paszportu.

44 Notatka w sprawie M. Dinescu i nastrojów opozycyjnych w Rumunii z 9.12.1989, AMSZ, nr. n. 37/93, w. 2., t. R., s. 41. List ten ambasada datowała na koniec kwietnia 1989 r., swój podpis pod listem wycofał ostatecznie Geo Bozga.

45 List R. Enescu do D.R. Popescu w sprawie M. Dinescu z 28.09.1989, thum. Kazimierz Jurczak, AMSZ, nr. n. 37/93, w. 2., t. R., s. 45-47. R. Enescu (1925-1994) był dziennikarzem, eseistą i krytykiem literackim, od 1966 związanym z czasopismem „Familia”.
} 
Z listem do Popescu wystąpił również 11 listopada 1989 r. Alexandru Paleologu, oskarżając przewodniczącego, że przyczynił się do fizycznego unicestwienia Dinescu i jego rodziny oraz na własną rękę podjął decyzję o pozbawieniu prawa do publikacji sygnatariuszy listu w jego obronie (wyjąwszy Geo Bozgę). Paleologu stwierdzał, że ta decyzja była zarazem bezprawna i śmieszna: bezprawna, bo nie miała oparcia w statucie Związku Pisarzy i śmieszna ponieważ:

...żadne administracyjne, bądź policyjne działania nie mogą usunąć poety, pisarza, artysty ze świadomości publicznej, w której istnieje. Może być on prześladowany, może ostatecznie zostać fizycznie unicestwiony - ale nic ponadto ${ }^{46}$.

Natomiast Dinescu 11 listopada wysłał do „Frankfurter Allgemeine” tekst Mamut i literatura. Tytuł nawiązywał do pewnego artykułu w zachodniej prasie: W Rumuniiostatni stalinowski mamut. Idąc za tą metaforą Dinescu dokonywał przeglądu trzewi stalinowskiego systemu w Rumunii, znajdując w nim szczątki protestujących z Doliny Jiu, Braszowa, Timoşoary, Klużu, Jasów, Târgu Mureş, Bukaresztu, a także jeszcze żywych ludzi znanych i zupełnie anonimowych, którzy mieli odwagę wykrzyczeć swoją rozpacz, nawet we własnych czterech ścianach.

W obliczu wszechobecnego w Rumunii strachu przed śmiercią Dinescu nie dostrzegał żadnej przestrzeni, czy instytucji, która niosłaby Rumunom wsparcie. Kościół prawosławny zastraszony „przypadkowymi” zgonami kilku kapłanów, dołączył do kultu dyktatora, bardziej bojąc się represji, niż „gniewu najwyższego”. Wsparcia nie dawał wymiar sprawiedliwości. Zdaniem Dinescu, studenci prawa, nauczani na studiach o wyższości lewicy rumuńskiej nad prawem rzymskim, uważali Konstytucję Rumunii za zwykly materiat propagandowy, diabelskie narzędzie, z którego nie należy korzystać przed sądem. Dinescu nie widział też wsparcia u dziennikarzy, nazywając ich apostołami kultu jednostki, piszącymi łyżką, którą ich karmiono. Nawet emigracja stała się niemożliwa, skoro, jak pisał poeta, berliński mur cegła po cegle, wystano na eksport $i$ odtworzono u granic Rumunii ${ }^{47}$.

Zdaniem Dinescu pozostawali jedynie „skrajnie nieliczni” rumuńscy dysydenci (jeden ujawniony dysydent na 2 mln mieszkańców), utrzymywani przez reżim przy życiu jedynie w celach propagandowych na użytek zachodniej prasy i instytucji obrony praw człowieka. Dinescu przekonywał jednak, że rumuński naród nie różnił się w swej woli wyrażenia sprzeciwu od Niemców, Polaków, czy Węgrów. Jego zdaniem w Rumuni było 20 mln protestujących, dysydentów, pozbawionych reklamy, caly czas zakneblowanych. Nie wytaczano im procesów politycznych, ponieważ Konstytucja gwarantowała obywatelom prawo do wyrażania własnych poglądów. Ulegali natomiast wypadkom w pracy, samobójstwom, ginęli w wypadkach komunikacyjnych,

46 List A. Paleologu do D.R. Popescu z 11.11.1989, brak nazwiska thumacza, AMSZ nr. n. 37/93, w. 2., t. R. s. 49-50. A. Paleologu był eseistą i krytykiem literackim, więzionym w latach 1959-1964. W 1989 r. pracował dla wydawnictwa Cartea Românească.

47 M. Dinescu, Mamut i literatura, s. 51-52. 
a ich rodziny znajdowały się w stałym zagrożeniu. W tej sytuacji Dinescu uważał, że rumuńscy pisarze, by ratować godność rumuńskiej kultury powinni zastrajkować. Gdyby jednak połączyli swoje słowa, rumuńskie mamuty jego zdaniem mogłyby opuścić karty historii i wkroczyć do podręczników botaniki, by paść się rumiankiem ${ }^{48}$.

\section{ZAKOŃCZENIE}

Opinia Dinescu o 20 milionach rumuńskich dysydentów okazała się bardziej trafna od tych, które formułowała polska ambasada w Bukareszcie. Jej pracownicy najwyraźniej nie doceniali wagi indywidualnych sprzeciwów, których świadectwa skrupulatnie odnotowywali. W raporcie dotyczącym nastrojów społecznych od lipca do września 1989 r. podkreślano, że niezadowolenie społeczne znajdowało wyraz w prywatnych rozmowach, wyrażano je w bardzo ostrożnej formie, a pojedyncze protesty intelektualistów i byłych przywódców partyjnych zostały skutecznie wyciszone i nie miały liczącego się wpływu na społeczne nastroje ${ }^{49}$.

Jeszcze 9 grudnia 1989 r. Łukasz Szymański donosił, że utrzymujące się, a nawet narastające nastroje opozycyjne nie przybierają żadnej zorganizowanej formy i nie mają oparcia w żadnej zorganizowanej sile społecznej, ani w aparacie władzy. Stwierdzał więc: Byloby zatem rzecza pochopna wyrokować rychty upadek obecnego porzadku w Rumunii ${ }^{50}$.

Jego opinia została zakwestionowana zaledwie sześć dni później, gdy 15 grudnia doszło do otwartego buntu w Timişoarze. Protest rozlał się na inne miasta, doprowadzając do upadku Ceauşescu i jego rodziny. Brakiem przenikliwości wykazali się nawet rumuńscy urzędnicy partyjni, którzy raczej liczyli na śmierć Ceauşescu ze starości, niż na społeczny bunt. Przyznał to 29 grudnia 1989 r. w rozmowie z Anną Husarską Corneliu Bogdan, przytaczając w odniesieniu do rumuńskiego społeczeństwa starą opinię, że mamałyga nie wybucha ${ }^{51}$.

Grudniowe wydarzenia w Rumunii w 1989 r. potwierdziły natomiast słuszność analizy Václava Havla, który wskazywał na ogromne znaczenie indywidualnej decyzji o odrzuceniu narzuconej gry pozorów i opowiedzeniu się za prawdą oraz ludzkim a nie ideologicznym porządkiem życia.

48 M. Dinescu, Mamut i literatura, s. 52, 54-55.

49 Notatka informacyjna z września 1989 r. o sytuacji w Rumunii w III kwartale 1989 r., AMSZ, nr. n. 37/93, w. 2., t. R., s. 27.

50 Notatka w sprawie Dinescu i nastrojów opozycyjnych w Rumunii z 9.12.1989, AMSZ, nr. n. 37/93, w. 2., t. R. s. 42.

51 Razem przeciw NIEMU. Rozmowa z Corneliu Bogdanem, przeprowadzona przez Annę Husarską, „Gazeta Wyborcza”, 3.01.1990 r. C. Bogdan był sekretarzem stanu i wiceministrem spraw zagranicznych wyłonionego po rewolucji rządu Rumunii; rozmowa przeprowadzona 29.12.1989 została opublikowana po jego nieoczekiwanej śmierci, 1 stycznia $1990 \mathrm{r}$. 


\section{BIBLIOGRAFIA}

\section{Źródła archiwalne:}

Archiwum Ministerstwa Spraw Zagranicznych w Warszawie

Nr nabytku 37/93, wiązka nr 2, teczka Rumunia.

\section{Opracowania i artykuly:}

Burakowski A., Geniusz Karpat. Dyktatura Nicolae Ceauşescu 1965-1989, Warszawa 2008.

Câmpeanu P., Ceauşescu, Warszawa 2004.

Havel V, Siła bezsilnych, tłum, Agnieszka Holland, w: V. Havel, Siła bezsilnych i inne eseje, Warszawa 2011.

Kunze T., Ceauşescu. Piekło na ziemi, Warszawa 2016.

Marie J.B., Praktyka Komisji Praw człowieka ONZ w zwiazku z naruszeniami praw człowieka, „Ruch Prawniczy, Ekonomiczny i Socjologiczny", t. 43, nr. 1, 1981, s. 1, 116 i inne, https://repozytorium. amu.edu.pl/bitstream/10593/21054/1/009\%20JEAN-BERNARD\%20MARIE\%20RPEiS\%2043\% 281\%29\%2C\%201981.pdf [dostęp: 16.08.2020].

Paţilea P. (Crângan), The Political discourse as ideological subversive act in the Romanian totalitarian age. Mircea Dinescu's case, „Procedia. Social and Behavioral Sciences” 2012, nr 63, https://www. sciencedirect.com/science/article/pii/S1877042812047507 [dostęp: 27.11.2020].

Păun N., La chute du Mur de Berlin, symboles et action en Roumanie, https://books.openedition.or/ cirac/265\#text [dostęp: 12.09.2020].

Willaume M., Rumunia, Warszawa 2004.

\section{Prasa:}

Buletin de stiri17 martie 1989, Radio Europa Liberă Râmania, Istoria trăită, Sorin Şerb, 16 martie 2019, https://romania.europalibera.org/a/buletin-de-stiri-17-martie-1989/29824981.html [dostęp: 12.09.2020].

Razem przeciw NIEMU. Rozmowa z Corneliu Bogdanem, przeprowadzona przez Annę Husarską, „Gazeta Wyborcza", 03.01.1990. 